\title{
Tourismification and Integration of Buganda's Culture in Community Socio-economic Activities for Poverty Reduction and Sustainable Development
}

\author{
Jockey Baker \\ Department of Forestry Biodiversity and Tourism, School of Forestry, Environment and Geographical Sciences, College of \\ Agriculture and Environmental Sciences, Makerere University, Kampala 7062, Uganda
}

\begin{abstract}
Buganda, one of oldest kingdoms in Uganda, has got a rich tangible and non-tangible cultural heritage which can be developed into cultural tourism products and integrated in the community socio-economic activities for national sustainable development. The paper highlights the major cultural heritage of Buganda, its development for tourism, integration in the daily socio-economic activities of the communities and contribution to SDGs (Sustainable Development Goals). Buganda's culture include: the Kings (Kabakas) burial grounds, Kabaka's lake and trail, music, dance, drama, handicrafts, traditions and food which provide an authentic cultural tourism product which compliments Uganda's nature tourism. Community participation and provide employment opportunities to the youth and women there by returning the tourism dollar to the community and this is important for sustainable development. The tourismification of Buganda's culture shall not only diversify Uganda's tourism industry but contribute to national sustainable development.
\end{abstract}

Key words: Tourismification, integration, culture, sustainability, tourism development.

\section{Introduction}

Tourism is believed to be the fastest growing industry globally $[1,2]$, with favorable developmental impacts on the economy, society, environment at local and national level [3]. However, it could also have negative impacts on the society and this duality is referred to as 'tourism first' and 'development first' [4-6].

It is the world's largest employer directly and indirectly employing 120 and 125 million people respectively contributing US $\$ 6$ trillion (9\% GDP) to the world economy [7]. Tourism in Uganda is dominantly nature based carried out in national parks, game reserves and protected areas. However, cultural tourism is growing steadily and of the 1,206,334 tourists registered in 2013, 188,000 were either leisure

Corresponding author: Nyakaana Jockey Baker, Ph.D., professor, research field: sustainable and cultural tourism development. or cultural tourists. Tourist expenditure contributed US 979 million to GDP compared to Kenya \$5.3 billion, Tanzania $\$ 4.8$ billion, Rwanda $\$ 0.7$ billion and South Africa 33.4 billion and Africa's average $\$ 85.4$ billion [8]. It contributes $38 \%$ of export revenue and $0.5 \%$ of Government taxes. “...US $\$ 1$ of expenditure by a foreign tourist generates, on average, of GDP US \$2.5" [9]. This is higher than the US \$2.3 generated by US $\$ 1$ of traditional exports. Tourism is significant because of the impact (direct and indirect) it has on the communities and destinations as the anticipated benefits of its development often lead to expansion of infrastructure, tourist facilities and inter sector growth linkages and is therefore intimately connected with sustainable development.

Buganda kingdom, one of the oldest and largest kingdoms in Uganda located in the South Central Region of the country has a diverse cultural heritage centered on Kasubi Hill one of the hills which make up Kampala city. On the hill top is the former palace 
of Kabaka (King) Muteesa 1 (the 31st Kabaka) built in 1882 and converted into the royal burial ground in 1884. The main house (Muzibu Azaala Mpanga) which was dome shaped and believed to have been the largest grass thatched house in the world got burnt on 16th March 2010. Being an old kingdom (12th Century to date), Buganda has accumulated and sustained a diverse and territorial coherent culture based on music and dance, spiritual healing, magic and ritual objects, cloth (olubugo), sacred sites and objects, handicrafts, palaces, foods and drinks. Despite being the most developed and urbanized region of Uganda, Buganda has maintained its cultural heritage. It is therefore important to utilize this rich culture for the socio-economic welfare of the communities and this can be achieved through tourism.

\section{Literature Review}

World over, there is now a trend to redefine the cultural identity of regions with a new emphasis on territorial expression of history, habitat and heritage by constructing representation of destinations for marketing purposes [10-12]. Culture can be used for tourism development as 'back-up' facilities for other forms of tourism, for example cultural tourism providing excursion possibilities to visitors who are in transit to other tourist areas [13].

Cultural tourism attractions include heritage, arts, creative, experiential and indigenous tourism. It could be rural or urban, natural or manmade [14]. Cultural resources can be driving forces of a nation or region and tourism dynamics [15], creation of new forms of holidays, tourists and 'post modernist' cultural forms [16]. To achieve this, they need to be explored in a Trans disciplinary approach as perceived mutual benefits drive the stakeholders towards common economic goals. Cultural tourism offers the opportunity to generate income for the community while simultaneously supporting the preservation of culture through the 'real' and 'imaginary' worlds of objects and phenomenon [17, 18]. It is seen as a valued tool for local social and economic development and could contribute to better livelihoods for the community hence sustainable development. Tourism development strategies aim at maximizing tourism benefits for improvement in human capital, employment, provision of public utilities and services, reducing the negative impacts and connection to the Millennium Development Goals, to fight hunger and poverty $[19,20]$. However, sustainable tourism development depends on community participation and empowerment as this raises the standard of living of the community, infrastructure development, and provision of tourist facilities and inters sector growth linkages at the destination [14]. Socio-economic linkages between the community and the tourism sector through supplies of products and services are a good stimulus for the communities and structural transformation of regions which are linked to SDGs (Sustainable Development Goals).

Tourism is an important economic activity that can promote regional development, redistribute wealth and utilize resources that are not viable for other economic activities like manufacturing and agriculture [21]. Tourism expenditure could be direct, indirect or induced and is an export between countries (international) and regions (domestic).

\section{Results and Discussion}

\subsection{Cultural and Historical Sites}

Cultural resources (Fig. 1) are dynamic and the first objective of this paper was to "identify the major cultural and historical sites/activities in Buganda". Buganda's cultural heritage is diverse, tangible (built) and intangible (unbuilt) and was meant to serve the cultural purposes of the Baganda. "Buganda our beloved kingdom has plenty of outstanding traditional places worth seeing and learning all about them so as to have the courage of preserving them and respecting them" [22].

Buganda's cultural and historical sites are located both in the rural and urban areas (Map 1). The 


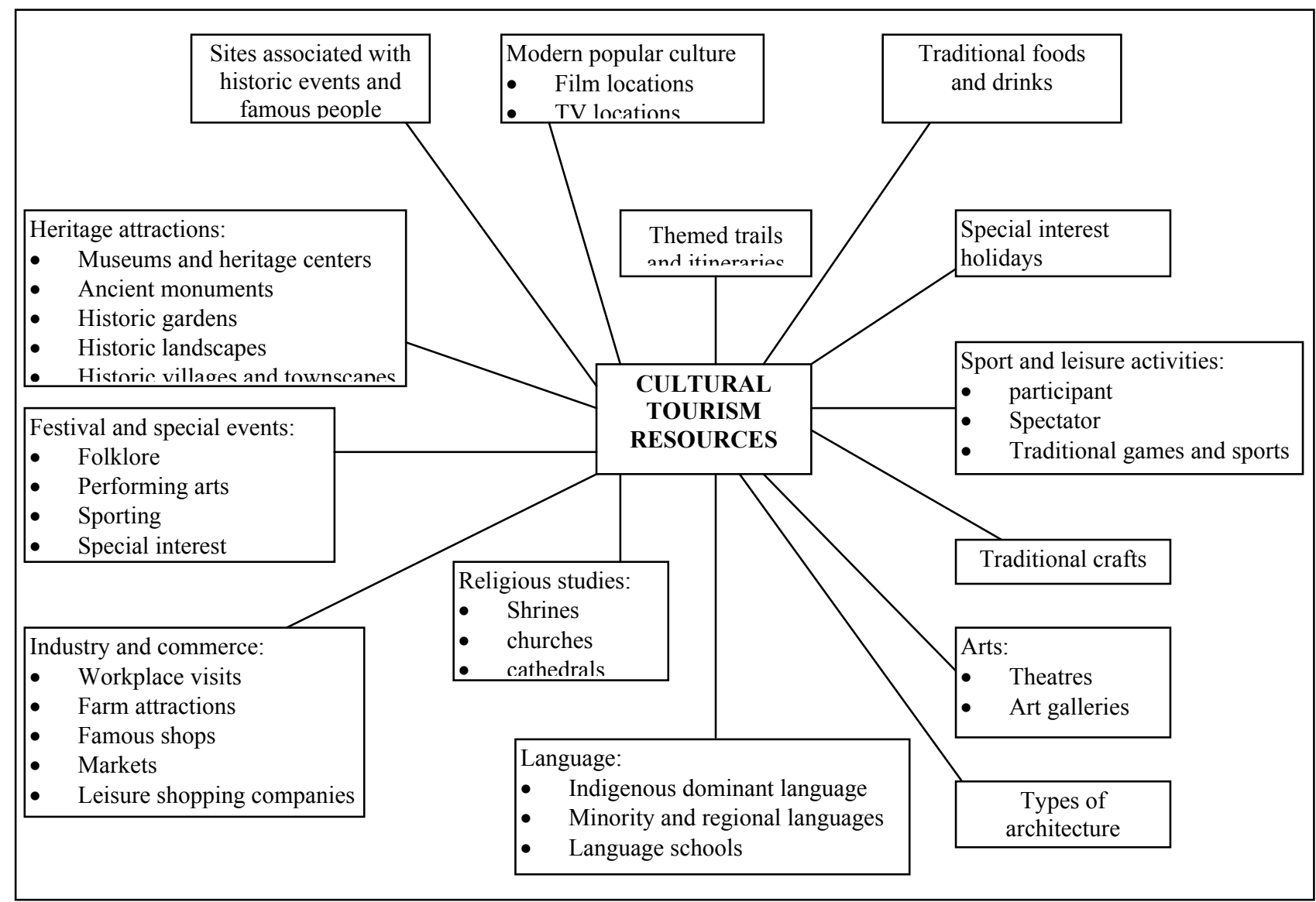

Fig. 1 Cultural tourism resources.

Source: Ref. [15].

tourismification process should be mindful of the daily socio-economic activities of the communities to avoid conflicts and to make the whole process sustainable.

3.1.1 Buganda's Major Cultural and Historical Sites

\section{(a) Kasubi Tombs}

Kasubi tombs (Amasiro-Royal tombs) are located on Nnabulagala hill three kilometers to the west Kampala city center. This was Kabaka Mutesa 1 (1856-1884) palace built in 1882 and converted into royal burial grounds in 1884 . There was a huge dome shaped grass thatched structure 'Muzibu Azaala Mpanga' (Plate 1) used as a burial ground (mausoleum) for Buganda kings and to date four kings are buried there. The mausoleum is only for the kings and other royals are buried outside. Unfortunately, this important cultural heritage got burnt on 16th March 2010 , and plans are under way to restore it to its former glory. On the compound there were other grass thatched structures used for different purposes. 'Bujjabukula' is the security house and entrance to the compound. 'Ndogoobukaba' is the store house for the sixteen Royal Drums "Mujaguzo" and the drums have been kept there since 1856 during Mutesa 1 reign [22-25]. The other houses are mausoleums for the different princesses and Kabaka's wives. The thirty predecessors of the four kings are buried elsewhere in the kingdom with twenty six being buried in Busiro County west of Kampala. The shrines (mausoleums) where they were buried are well maintained and can be developed for cultural tourism. Kasubi tombs are an UNESCO (United Nations Educational, Scientific and Cultural Organization) heritage site and are visited by both domestic and international tourists. The revenue realized from entry charges was used in maintaining the grounds and kingdom activities. 


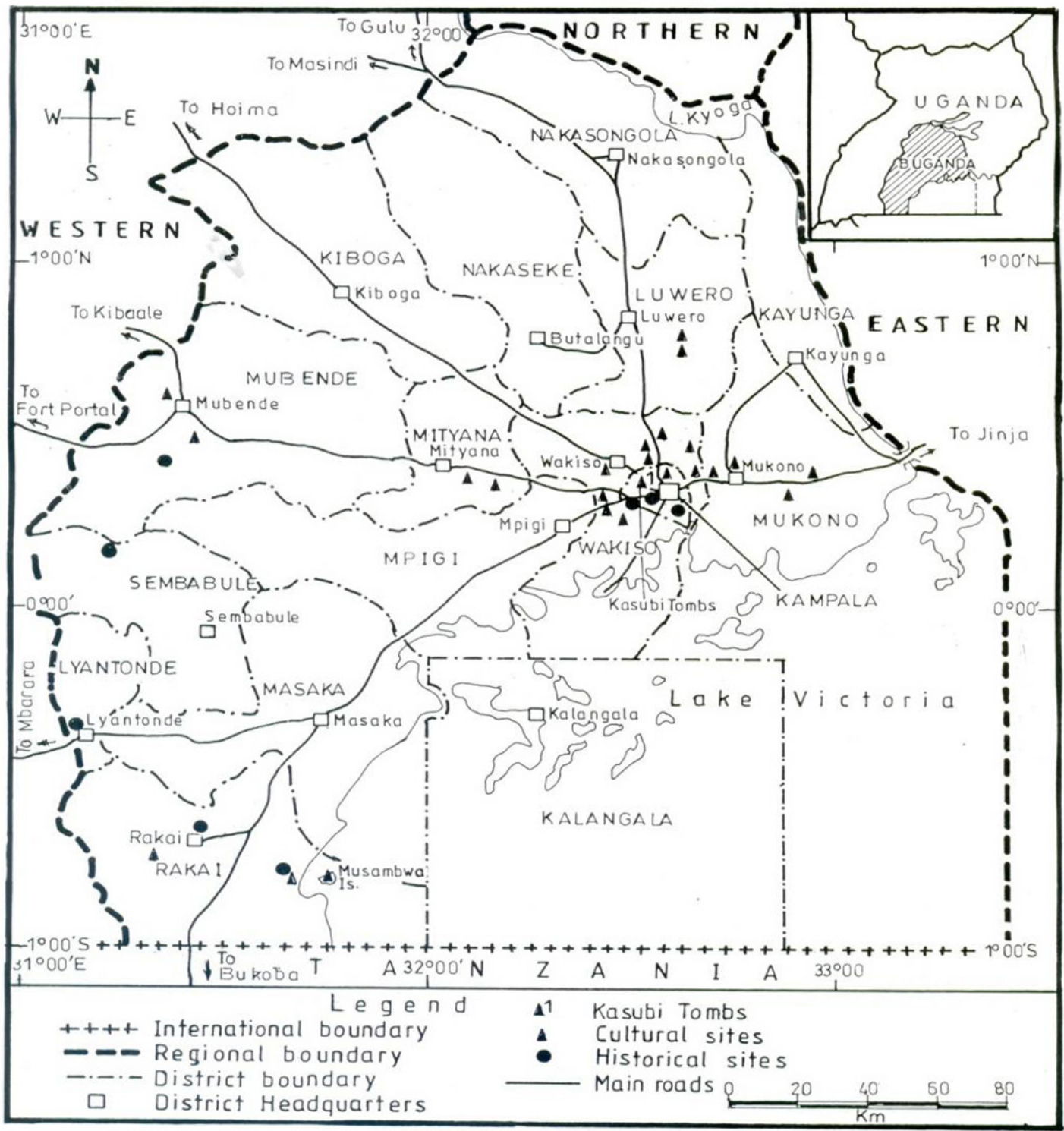

Map 1 Buganda heritage sites.

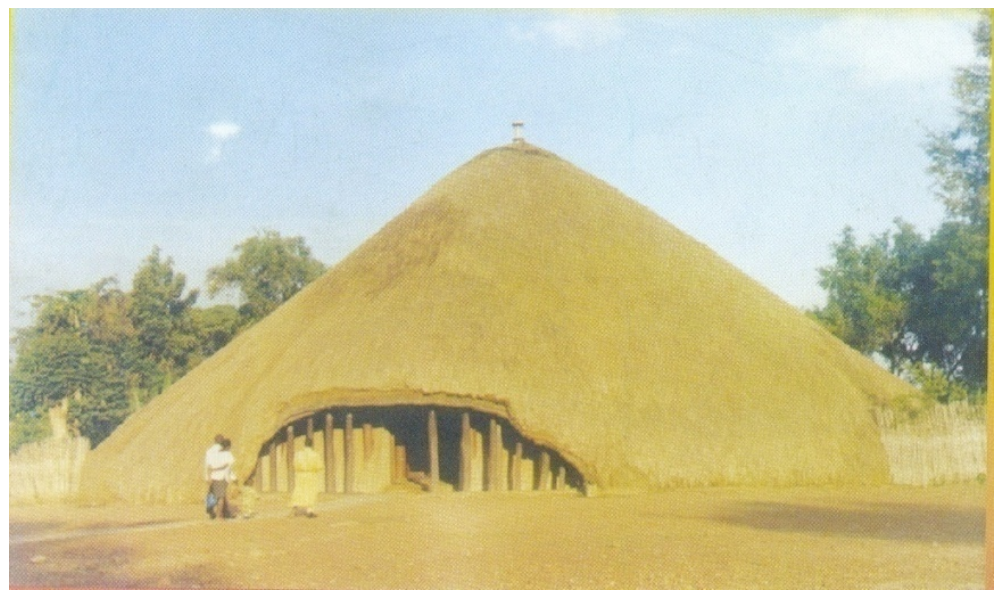

Plate 1 Kasubi Tombs (burnt on 16th March 2010). 
This site should be more advertised and integrated in the tourism itinerary of tourists visiting the national parks. Its history should be properly documented alongside the tourism literature of Uganda.

(b) Kabaka's Lake

The Kabaka's lake located 500 meters from Lubiri palace is an important landmark in Buganda's history. The lake was excavated on the orders of Kabaka Mwanga II in 1885. It was supposed to link with Lake Victoria through a $20 \mathrm{~km}$ canal and would be used as an escape route in case of attack. Mwanga's plans of beautifying the lake shores and constructing the canal were not completed by his successors. However, the lake has important birds living in the papyrus vegetation and some cultural rituals are performed here annually. The lake shore could be planted with gardens, construction of bird watching towers, water sports like boat racing, scuba diving and swimming and an international hotel could be constructed here. These developments would attract both domestic and international tourists, create employment (direct and indirect) and help reduce on poverty levels among the community.

(c) Kabaka's Trail

Buganda has had kings since the 12th Century and the social-culture story through the Kabaka's trail links a series of cultural sites (Map 2) which are within easy reach of Kampala. The sites on this trail include:

Naggalabi-Buddo - coronation site and the very heart of the kingdom;

Katereke Prison-where the earth speaks of betrayal and murder;

Wamala King's tombs - a place of ritual and ceremony;

Naamasole Kanyange Tombs-linking mother and son forever;

Ssezibwa Falls-beauty and healing in harmony.

Nnamasole Baagalayaze Tombs and Cultural centre - a place of hope, celebration and learning. Each can be visited on its own, or as part of the whole trail. Each of these sites has a unique story to tell which enables one to experience a rich and authentic culture, learn about forgotten times and come face-to-face with ancient traditions and ceremonies [26].

This trail is important in keeping Buganda's culture alive and if integrated in Uganda's tourism products would enable both domestic and international tourists get the gist of Buganda's culture. The product is unique to Uganda and would diversify her tourism products and markets which are important for the sustainability of the industry as cultural tourists look for unique communities and products which are unpolluted, close to perfection, the guardian of truth, beauty and goodness [28].

(d) Namugongo Martyr's Shrine

Namugongo Martyr's shrine six kilometers to the North East of Kampala is a symbol of brutality and holiness. Brutality because twenty-two young Christian converts who were Kabaka Mwanga II royal servants were executed (burnt) on his orders for refusing to denounce Christianity. There was holiness because it depicts devotion of the young converts to Christianity. They preferred death to disowning Christianity. Artist impressions depicting the different scenes of the execution grace the whole place and the bones of Karoli Muwanga one of the martyrs are kept in the shrine. The 3rd of June (Martyr's Day) is a public holiday in Uganda. Pilgrims come from around the world to grace the day. Such an important occasion, in the Christian calendar needs to be vigorously marketed and packaged in the tourist itinerary.

(e) Other cultural Sites

Buganda is well endowed with other cultural products like scared hills, trees, (e.g. Nakayima tree in Mubende; Plate 2), shrines, caves and waterfalls scattered all over the kingdom. The surrounding communities and Baganda in general have significant attachments to them. They are used for spiritual healing and cultural rituals by the traditional healers (Basamize) and their followers. These places need to 


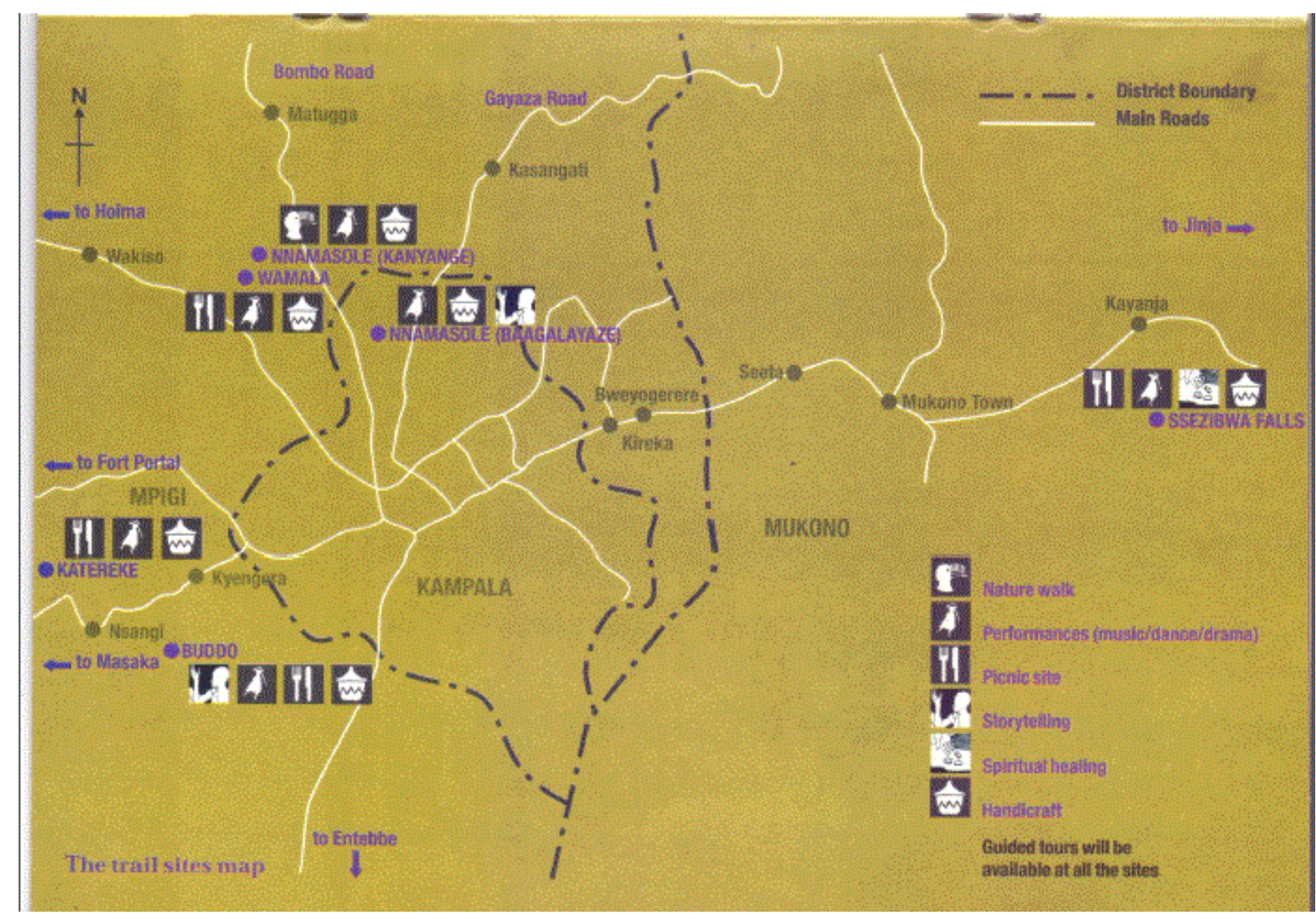

\section{Map 2 Kabaka's trail.}

Source: Ref. [27].

be conserved, made accessible and properly maintained so that cultural tourists can be encouraged to visit them. The ministries responsible for Culture, Tourism and Antiquities should join hands and make sure these cultural products are properly developed and advertised for cultural tourism. This will broaden Uganda's tourism base, attract a new category of tourists, create employment opportunities for the communities (direct, indirect) and increase their earning capacity and that of the economy through both back and forward linkages.

Buganda has a strong and diverse unbuilt (intangible) cultural heritage through music, dance and drama, art and handicrafts. The handicrafts include mats, baskets, drums, beadworks and necklaces made from natural materials like papyrus, bamboo, sisal, palm tree leaves, banana fibers, climbers and bark cloth. The involvement of communities in the making and marketing of these products is very important in the fight against poverty. Bark cloth which is unique to Buganda could be developed as a special tourist product where tourists are taken through the process of making it i.e. from the bark of a tree (fig tree-mutuba) to that special cloth used for making special ceremonial wear, decoration and handicrafts.

The Baganda should be encouraged to retain their heritage intact for the development of cultural tourism. Uganda Tourism Board, Ministry of Tourism and Tour Operators should market this attraction vigorously by integrating it in tourism plans, market channels (brochures, internet) and itineraries.

\section{Tourismification of Buganda's Culture}

Tourismification is a process of developing a resource into a tourism product (tangible or intangible) 


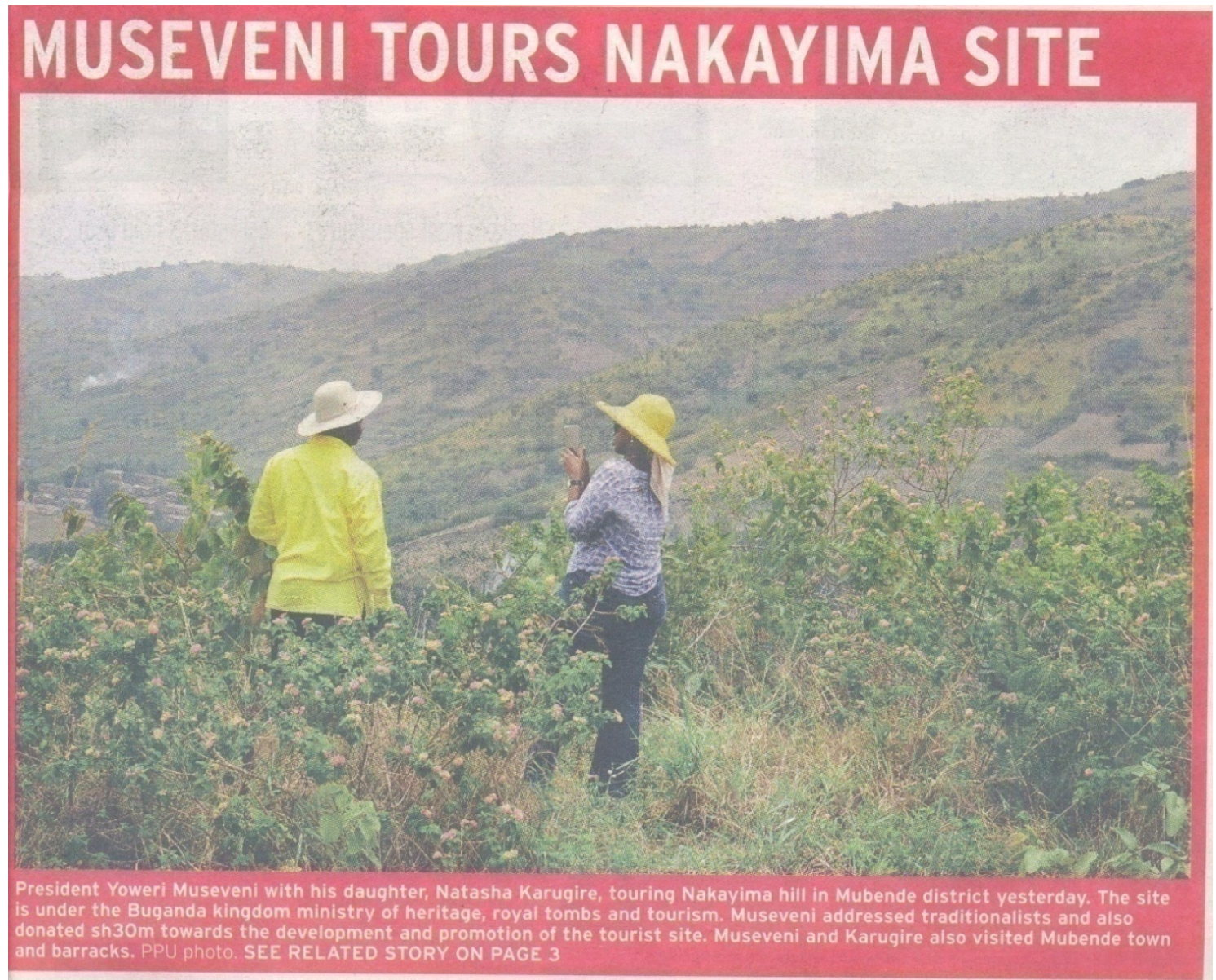

Plate 2 Nakayima site Mubende district.

Source: Ref. [29].

attractive to tourists and the tourismification of Buganda's culture was the second objective of this paper. Development of the cultural and historical sites and the associated activities into tourism products requires setting up a clear cultural tourism system (Fig. 2) where the different stakeholders are brought on board and enabled to play their roles. Within the system, the public (government-central and kingdom), private sector and community should play their roles as partners and not competitors. The public sector should manage and promote the resources through destination marketing, while the private sector not only manages the resources but provide the intermediary and support services [15]. The community should provide community security and management services to some of the resources and active participation in the provision of the intermediary and support services e.g. music, dance, crafts and sports. The tourism activities should be integrated in the daily cores and socio-economic life of the communities especially in the rural areas. Through training, communities should be empowered to improve the quality of the products, reduce the likelihood of conflict, ensure sustainability, increase ownership of the heritage and enhance its management [18].

The cultural landscapes should be oriented to tourism through protection and conservation policies of tangible heritage, skills and creativity in transforming cultural resources into drivers of a cultural economy and the capacity to integrate cultural assets in a dynamic and innovative tourism landscape. It is not only the quality of heritage sites which matters but most important the quality of conservation, 


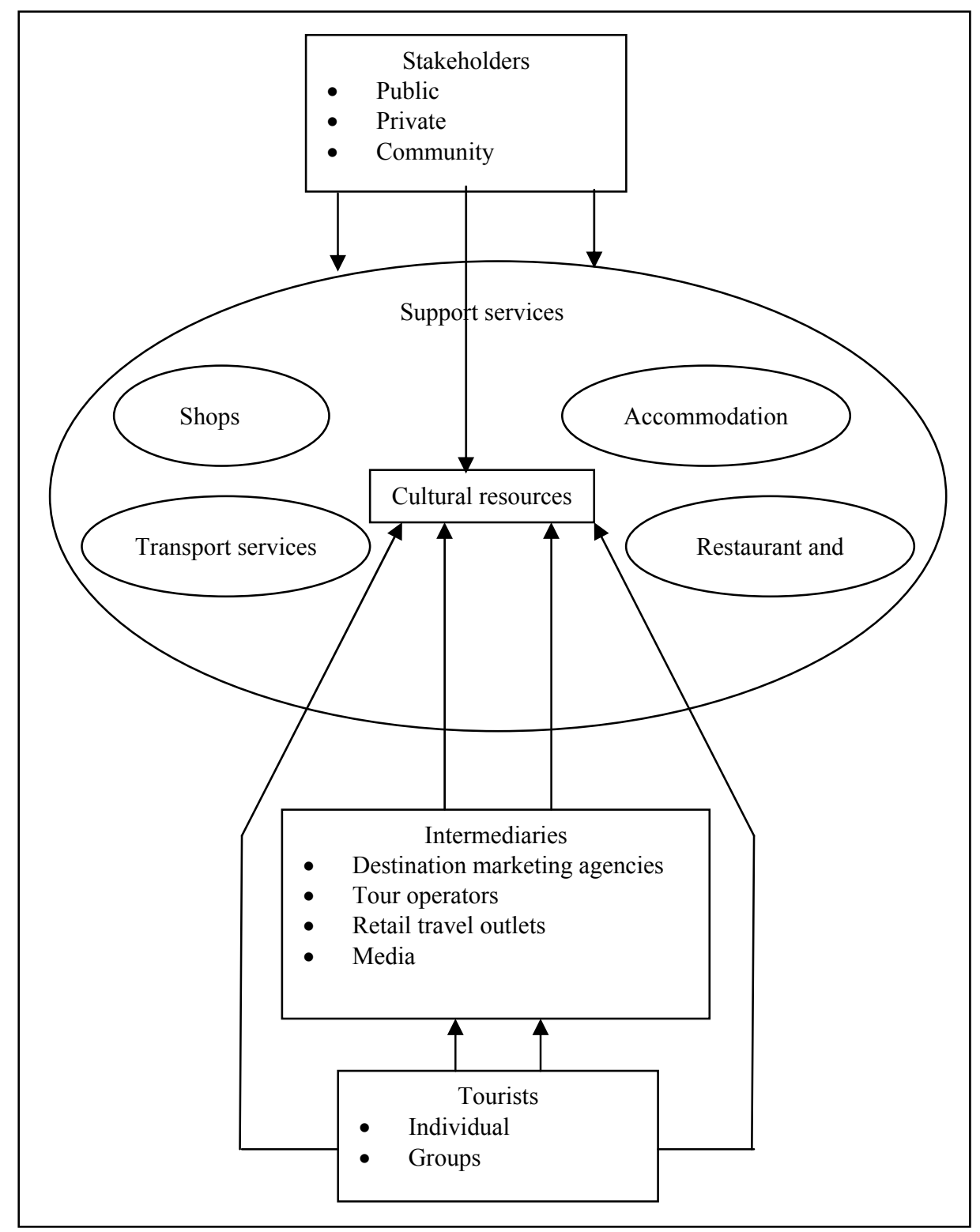

Fig. 2 A cultural tourism system.

Source: Ref. [15].

the creativity of landscaping between buildings, natural landscapes and artifacts, diversity, variation and territorial coherence of the cultural resources [12]. It is the task of the Buganda government, in collaboration with academics, central government and private sector, international organizations to develop skills to manage, monitor and evaluate changes in the use of Buganda's cultural heritage resources. The ultimate paradox is between the conservation policies for heritage sites and 'protected' cultural landscapes and development strategies geared at capitalizing on tourism potential. There is need to find a balance between conservation and the use of heritage sites for tourism as it is perceived to be the core income generating activity [18].

\section{Integrating Cultural Tourism in the Community Socio-economic Activities}

The success of the development of cultural tourism depends on the integration of tourism in the daily cores of the community.

Our third objective was to "ascertain the level of 
tourism integration in the daily cores of the communities where cultural tourism has been developed". Integrating cultural tourism in the daily activities of the community means consciously setting out to maximize the economic, social and environmental benefits of cultural tourism for the host community [15]. It ensures participation, sustainability and acceptability and take different forms and at different levels and could be direct or indirect. It is important to involve all those affected by the proposed tourism development in the planning process as to have an effective integrated activity.

Successful integration requires community participation which ranges from the least to the most involvement could be direct or indirect. Butler identified five levels of participation namely imposition, petition, advice, representation and equality [18]. Direct participation is where the communities are involved in the provision of support services like accommodation, restaurants, and bars, tour guiding, music, dance, drama and handicrafts. Uganda tourism policies emphasize a bottom-up approach in tourism development and community participation as entrepreneurs. Through district planning, communities are sensitized and encouraged to appreciate the value and cultural resources for tourism development [27]. Successful community projects for accommodation, tour guiding services have been established around protected areas; similar projects could be started around Buganda's heritage to benefit individuals directly and communities through establishment of community projects and create employment opportunities for the youth and women. Through participation in decision making, the communities determine their own development goals and have a meaningful voice in the organization and management of tourism in the area [28].

\subsection{Forms of Integration}

Integration takes different forms depending on the nature of the cultural resources and other resources, community needs and capacity, and government policies. It could involve combining multiple elements and cultures which offer unique experiences where guests can share the excitement and warmth of true rural African Culture [6].

\subsubsection{Setting up Business Linkages}

Since tourists require accommodation and food, community members could come together and set up business links to establish accommodation and eating facilities. Farmers as self-employed supply fresh products at quantity, quality and price demanded by the market. In Tobago, farmers earn between 30\%-100\% more than the normal and in the Gambia, $90 \%$ of the members are women [19]. Farm and Gastronomic tourism as is done in France [15], the 'fermes-auberges' scheme allows farmers to provide meals for tourists based on locally produced food stuffs. It could be the 'Adopt a Farmer' or 'Taste of Tobago' approach developed in Tobago or 'Gambia is good' in the Gambia. In the three cases, farmers, hotels and restaurants come together and set up business links. The combination of farm accommodation and provision of food will greatly enhance community participation and economic base. The same community entertains the tourists at a fee and sells their handicrafts directly without intermediaries who enable them earn high profits. In Uganda, this has been successful at KAFRED (Kibale Association for Rural and Environmental Development) a Community Based Organization on the fringes of Kibale Forest National park in Western Uganda which combine conservation and tourism [29]. Elsewhere in Uganda, NCDF (Nkuringo Community Development Foundation) and BCCT (Bwindi Community Conservation Trust) on the fringes of Bwindi National Park have combined cultural tourism in their daily cores. The communities benefit from the tourist dollar through cultural tourism, employment (tour guides), contribution to community projects (schools, health facilities), sale of handicrafts and entertainment to tourists. 


\subsection{Cultural Villages}

Integration could be through establishment of cultural villages (visitor homestead) similar to the visitor metse of Blouberg in South Africa [28] based on the three product models (core, tangible and augmented products) developed by Swarbrooke, J. [30]. The concept of cultural villages has been successful in Southern Africa in the Lesedi and Swazi Cultural villages [6]. The core product is what attracts the tourist and in the case of Buganda it is the cultural heritage which is both tangible and intangible. The intangible culture should be made tangible-an entity which customers can purchase to satisfy their needs [28]. The augmented products are the facilitates provided for tourist comfort and satisfaction. The establishment of cultural villages should ensure community participation in decision making and involvement in the benefits of tourism. In the villages on site, Buganda culture is presented through touristic narratives, displays, spectacles and shows by the communities. The villages display the authentic and uniqueness of the place. The distant past is merged with the present day situation and social context. The community is involved in small scale family driven services to the cultural village alongside their daily socio-economic activities and this ensures sustainability and increased earning capacity of the community. The locally owned enterprises increase multiplier effects in the host community, reduce on leakages, increase employment opportunities and reduce migration in search of employment. The Bombo Community Tourism Initiative (40 km to the north of Kampala) is made up of home stays, a women's handicraft group, traditional dancers and a mini cultural center. Selected homes were upgraded by COBATI (Community Based Tourism Initiative) to host tourists. Families were trained on visitor handling, nutrition, hygiene, sanitation and waste management. Participating families have had their household income increased as they earn directly from the tourists. The main challenge is the low tourist numbers.
The integration process should be linked to three critical parameters, namely community awareness, unity and power or control relationships both internal and external [31]. The tourismification process should sensitize the communities on their roles, benefits and costs associated with cultural tourism and once accepted then it is introduced and integrated in the daily socio-economic activities of the community. The success of this integration will depend on the quality of the product to attract repeat tourists and get positive recommendations to friends and relatives. Sensitize and controversial issues on ethnic, ethics, traditions should be discussed openly and cultural tourism should be democratized and not made an elitist activity.

\section{Challenges and Constraints}

The first challenge of tourismification and integration is resistance from the conservative communities who prefer the status-quo. This requires intensive and extensive sensitization, training and on-site visits to success areas both in and outside Uganda. The relevant stakeholders (Non Government Organizations, Community Based Organizations, Government-Central and Kingdom, Private sector and Academics) would have to team up to undertake this important exercise.

The cost implications are very high and this requires government and development partners commitment to invest for the future. Identification of viable cultural tourism products, their development and marketing is another challenge. Academics, tourism development partners, private sector and government would have to work together to develop strategies to overcome this challenge.

Some of the sites are located in remote areas that require communication and infrastructure development. The government takes the lead and the private sector would set up tourism infrastructure especially accommodation. Trained/skilled human resource to manage cultural tourism products is vital 
but lacking in Uganda. The communities would need to be empowered (financial and knowledge) to take responsibility for Tourism in their communities. They need continuous training programs to become entrepreneurs and participants in and beneficiaries of the tourism industry [31]. This would require tertiary academic institution to take on the challenge and train the relevant personnel.

There should be hands-on training and re-training of the available personnel by both local and international experts. Though the current tourism policy addresses cultural tourism, it lacks focus on conservation and development of cultural heritage for tourism. The government should come up with a policy and master plan on tourism development which integrates cultural and natural resources. The policy should be harmonized with the relevant policies on environment, conservation, health, building, communication, etc..

\section{Conclusion}

Buganda has a rich cultural heritage which has been preserved since the 12th Century. This heritage needs to be utilized for the socio-economic welfare of the community which has endeavored to preserve it. The heritage should be used for cultural tourism development where the three pillars of sustainability (Place, Profit and People) can be achieved by integrating cultural tourism initiatives in the daily socio-economic activities of the communities. All stakeholders especially the communities should be involved in all the stages of the Tourismification process so that they own and benefit from the cultural tourism initiatives.

\section{References}

[1] Campbell, L. M. 1999. "Ecotourism in Rural Developing Communities." Annals of Tourism Research 26 (3): 534-53.

[2] WTO. 2003. Africa: Tourism Market Trends. World Tourism Organization. Madrid. Spain.

[3] Saarinen, J., and Niskala, M. 2009. "Selling Places and Construction Local Cultures in Tourism: The Role of the
Ovahimba in Namibian Tourism Promotion." Tourism Strategies and Local Responses in Southern Africa: 61-72.

[4] Burns, P. 1999. "Paradoxes in Planning Tourism Elitism or Brutalism?" Annals of Tourism Research 26 (2): 329-48.

[5] Saarinen, J. 2006. "Traditions of Sustainability in Tourism Studies." Annals of Tourism Research 33 (4): 1121-40.

[6] Saarinen, J. 2007. "Cultural Tourism, Local Communities and Representation of Authenticity: The Case of Lesedi and Swazi Cultural Villages in Southern Africa." Culture and Community: Tourism Studies in Eastern and Southern Africa: 140-54.

[7] Blanke, J., and Chiesa, T. 2013. "The Travel and Tourism Competitiveness Report. Reducing Barriers to Economic Growth and Job Creation." World Economic Forum. Geneva.

[8] Ministry of Tourism, Wildlife and Antiquities. 2014. Statistical Abstract. Government of Uganda. Government Printer, Entebbe.

[9] World Bank. 2013. Economic and Statistical Analysis of Tourism in Uganda. World Bank Group. Washington.

[10] Echtner, C. M., and Prasad, P. 2003. "The Context of Third World Tourism Marketing." Annals of Tourism Research 30 (3): 660-82.

[11] Jenkins, O. H. 2003. "Photograhy and Travel Brochures: The Circle of Representations." Tourism Geographies 3 (5): 305-28.

[12] Jansen-Verbeke, M. 2009. "Tourismification of Cultural Landscapes: A Discussion Note.” Resources Science 31 (6): 934-41.

[13] Nyakaana, J. B. 2001. "Cultural Tourism Development for Sustainable Development in Uganda." Cultural Tourism in Africa: Strategies for the New Millennium: 235-42.

[14] Smith, M. K. 2009. Issues in Cultural Tourism Studies. Routledge. New York.

[15] Swarbrooke, J. 1999. Sustainable Tourism Management. CABI Publishing. Oxon, UK.

[16] Mowforth, M., and Munt, I. 1998. Tourism and Sustainability: Development and New Tourism in the Third World, 2: a rev. uppl. 2003. Routledge. London and New York.

[17] Hottala, P. 1999. The Intercultural Body: Western Woman, Cultural Confusion and Control of Space in the South Asian Travel Scene. Dept. of Geography No.7 University of Joensuu. Joensuu, Finland.

[18] Aas, C., Ladkin, A., and Fletcher, J. 2005. "Stakeholder Collaboration and Heritage Management." Annals of Tourism Research 32 (1): 28-48.

[19] Meike van de Wouw, 2008. Linking is Thinking: Linking 
Agricultural Producers and Tourism: An In-depth Study of the Opportunities and Constraints. (M Sc) Leisure, Tourism and Environment (MLE) Wageningen, University. The Netherlands.

[20] Ahebwa, M. W., Aporu, J. P., and Nyakaana, J. B. 2016. "Bridging Community Livelihoods and Cultural Conservation through Tourism: Case Study of Kabaka Heritage Trail in Uganda." Tourism and Hospitality Research 16 (2): 103-15. DOI: 10: 1177.

[21] Pearce, P. L. 1991. Tourist Development (Second Edition). Longman Group UK.

[22] Wavamunno, G. 2004. The Traditional Places in Buganda. Wava Books Ltd., Kampala.

[23] Senteza, G. 2004. Inside the Kasubi Tombs: Discover the Secret History of Buganda. Skimka Associates, Kampala.

[24] Buganda, 2002. The Kabaka's Trail. Walking in the Steps of the Kings. Fountain Publishers. Kampala.

[25] Wanjohi, K. 2002. "Cultural Tourism: A Trade-off between Cultural Values and Economic Values." Cultural Tourism in Africa: Strategies for the New Millennium: 109-24.

[26] Presidential Press Unit. 2016. "Museveni Tours
Nakayima Tree." New Vision News Paper: 1.

[27] Nyakaana, J. B., and Edroma, E. 2008. "Integrating Wildlife in Natural Resources Management for Tourism and Community Livelihoods in Lake Victoria Basin: East Africa." African Journal of Environmental Science \& Technology 2 (10): 287-95.

[28] Boonzaaier, C. 2009. "6 The Applicability of Government Policy to Community-Based Catering Services: The Hananwa of Blouberg, Limpopo Province." Tourism Strategies and Local Responses in Southern Africa: 73.

[29] Nyakaana, J. B., and Ahebwa, W. M. 2011. "Governance of Community-Based Tourism in Uganda: An Analysis of the Kibale Association for Rural and Environmental Development (KAFRED)." New Alliances for Tourism, Conservation and Development in Eastern and Southern Africa: 63-81. Eburon.

[30] Swarbrooke, J., and Page, S. J. 2012. Development and Management of Visitor Attractions. Routledge.

[31] Okech, R. 2007. "The Role of Local Communities in the Management of Cultural Landscapes: Reflection on African Heritage Sites." Culture and Community: Tourism Studies in Eastern and Southern Africa: 49-59. 